\title{
SOCIODEMOGRAPHIC AND CLINICAL PROFILE OF HANSEN'S DISEASE PATIENTS IN A SPECIALIZED CENTER
}

\author{
PERFIL SOCIODEMOGRÁFICO E CLÍNICO DE PACIENTES COM HANSENÍASE \\ EM UM CENTRO ESPECIALIZADO
}

\section{Eliana Maria GAUDENCI푸 Giovanna Gaudenci NARDELLI²; Cíntia Tavares CARLETO³; Leila Aparecida Kauchakje PEDROSA ${ }^{4}$}

1. Enfermeira da Estratégia Saúde da Família pela Prefeitura de Uberaba/MG - Mestre em Atenção à Saúde pela Universidade Federal do triângulo Mineiro - SS/PMU, Uberaba, MG, Brasil; 2. Enfermeira - Doutoranda em Atenção à Saúde pela UFTM (PPGAS/UFTM), Uberaba, MG, Brasil. giovanna.gnardelli@gmail.com; 3. Enfermeira - Doutora em Atenção à Saúde pela UFTM -

NAE/PROACE/UFTM, Uberaba, MG, Brasil; 4. Professora Associada, Doutora, Instituto Ciências da Saúde - UFTM, Uberaba, MG, Brasil.

\begin{abstract}
This study aimed at highlighting socioeconomic and demographic conditions, clinical characteristics, disease trajectory and disability level among people with Hansen's disease. Observational, transversal and quantitative study. Developed in the city of Uberaba (MG) during september and octuber of 2014. The population of this study was composed by all patients diagnosed with Hansen's disease who have been being treated for the illness for at least 30 days $(\mathrm{n}=32)$. Most respondents were male $(59.4 \%)$. Their age averaging at 49.28 years. $46.9 \%$ were brown skinned, $40.6 \%$ were single, and $40.6 \%$ had completed basic education. Skin patches were the most perceived symptom (43.8\%). $81.3 \%$ of patients are multibacillary and $18.8 \%$ are paucibacillary. The degree of the physical disability was 0 for $18.8 \%$ people, and 1 for $37.5 \%$ of people, while $18.8 \%$ had the second degree. Correlations were found regarding age, familial income, and current status regarding both profession and education, all of those to the second degree of physical disability. The evaluation of patients should be routinely conducted, as would help in the achievement of early diagnoses, which would help to avoid the physical disabilities which significantly compromise the quality of life of this population.
\end{abstract}

KEYWORDS: Leprosy. Health Profile. Population Studies in Public Health.

\section{INTRODUCTION}

Throughout the ages, Hansen's disease has been considered a repugnant disease, contagious and incurable, especially because of the physical disabilities which lead to the social exclusion of its victims. For a long time, they were confined and treated in "Leper Colonies", clearly despised and unwanted, having to wear especial clothes that would identify them and make a ratchet or little bell sound in order to let the healthy know they were coming (MONTEIRO et al., 2013).

A disability-provoking disease leads to difficulties in tasks that are necessary for individual independence. It can restrain one's ability to do any activity in a way that is seen as normal for any human beings. That is how the World Health Organization - WHO (1981) - defines a disabling disease.

The disease must be studied in all its complexity, as these dismaying symptoms are not all; as it progresses, peripheral nerves can be affected, leading to a physical disability which occurs mainly as a result of late diagnoses (RODINI et al., 2010).

According to Miranzi, Pereira and Nunes (2010), the Health Department of the City of
Uberaba, city located in the country side of the state of Minas Gerais, in Brazil, has recorded 455 cases of Hansen's disease in the period between 2000 and 2006, averaging at 65 new cases a year, which represents 27 cases/100.000 inhabitants every year. In Brazil, between 2012 and 2016151.764 new cases were diagnosed, specific on 2016 we had 25.218 new cases and a detection tax of 12,2 cases for 100.000 habitants (BRASIL, 2018).

Brazil follows the classification used by Madri, were we can assign the following types of diagnoses: Indetermined, Tuberculoid, Borderline and Virchowian. The initial stage of Hansen's disease is called indeterminate (I) and is generally transient, and may progress to spontaneous cure, every person infected by the bacillus pass through this phase. Tuberculoid form (T) is the form of the disease in which the person's immune system succeeds in destroying the bacillus spontaneously. Bacilloscopy is negative for both of this forms. Leprosy T, along with I, constitute the pacibacillary form of leprosy (BRASIL, 2017).

The multibacillary form consists of leprosy of dimorph (D) and virchowian (V), the latter resulting from the inability of the immune response to prevent multiplication and elimination of the bacillus. The $\mathrm{D}$ form is generally characterized by 
showing several patches of reddish or whitish, with high edges, poorly delimited on the periphery (BRASIL, 2017).

According to the WHO (2001), it is not possible to treat Hansen's disease in a fragmentary way: mental, physical and social health are deeply intertwined when it comes to this disease. Therefore, all the different dimensions of the disease must be understood, as it does not affect only the physical body, but life as a whole, specially when it comes to the stigma and the prejudice (WHO, 2001). It is necessary to highlight how important a multidisciplinary team is. According to the Ministry of Health, every professional needs to worry about understanding and offering an integral assistance, which needs to be enriched by the opinions, prejudices, and knowledge that the patients notice in their routines (BRASIL, 2002).

Thus, this study aimed to evaluate socioeconomic and demographic conditions, clinical characteristics, disease trajectory, and disability level among people with Hansen's disease who are being treated at a Specialized Center and their possible correlations.

\section{MATERIAL AND METHODS}

Observational, transversal, quantitative study. Developed in the city of Uberaba (MG), in the Health Center Professor Eurico Vilela. The population of the research was composed by all the patients diagnosed with Hansen's disease, who have started their treatment for at least 30 days, signed the Free Consent Form and are older than 18 years old.

The study used a structured Form with data and variables which contemplated socioeconomic, demographic and clinical characteristics, together with the disease trajectory. A private room was used to conduct the interviews, guaranteeing the comfort and privacy of the respondent. The collected data occurred between during september and octuber of 2014 and the data was managed through the software Excel@, validated through double entry and statistical analysis, and executed in the program Statistical Package for the Social Sciences, version 20. In order to analyze the data, descriptive analyses were conducted for each quantitative variable (average, median, maximum, minimum, and standard deviation). In order to check for possible correlations among socioeconomic, demographic, clinical characteristics, and disease trajectory, the Pearson's $r$ test was conducted among quantitative variables (bivariate), and the Spearman's correlation was used to analyze cases in which one of the variables were ordinal. The significance level for the tests was $0.05 \%(\mathrm{p}<0.05)$.

This research was submitted to the approval of the Research Ethics Comittee (CEP) at the University at the Triângulo Mineiro (UFTM) under protocol No. 2173, regarding ethical concerns in researches that involve human beings, as it is required by the National Council of Health (Law 466/12). It needs to be noted that this study is an excerpt of the thesis "Quality of Life, Depression and Physical Disability in People with Hansen's Disease attended at a Specialized Unit".

\section{RESULTS}

This study was conducted with patients diagnosed with Hansen's disease in any of the forms the disease, who are being treated for at least 30 days. 43 patients who met the inclusion requirements were invited to participate; $75.43 \%$ of the population (57 patients in total). Since some respondents did not want to participate, the sample consisted of 32 participants $(74,41 \%)$. Socioeconomic/demographic characterization, presented in Table 1. Age has varied from 22 to 89 years of age, averaging at 49.28 years (standard deviation of 16.93 years).

It can be noted that most people $43.8 \%$ are patients with familial income between one and three minimum wages. However, it is important to mention that $28.1 \%$ earns up to one minimum wage, and $15.6 \%$ do not have a permanent income (eventually has work).

The occupations found (Table 1) were mostly in the general service area, where qualification is not essential, as traders and salespeople, bricklayers, seamstresses, street cleaners, manicure and school cook, to a total of $56.3 \%$. Retired people and housewives and husbands both represented $15.6 \%$. Students represented $12.5 \%$.

Regarding the characteristics of the disease and its trajectory, data was expressed in Table 2, which follows.

Regarding the variable "first perceived symptoms", skin patches had the greatest percentage, with $43.8 \%$. Data regarding the search for health services (Table 2) indicated that $53.1 \%$ of patients, after noticing their first symptoms, went to a Primary Health Unit (UBS), in order to be evaluated; $37.5 \%$ of people went to the specialized outpatient clinic Health Center Professor Eurico Vilela. The time passed between the surfacing of the first symptoms and the beginning of treatment (Table 2) was from 10 to 12 months and the 
average time for the start of the treatment was of 4.54 days.

Table 1. Socioeconomic/demographic data of patients diagnosed with Hansen's disease who are under treatment (gender, age, skin color, marital status and education). Uberaba-MG, 2014

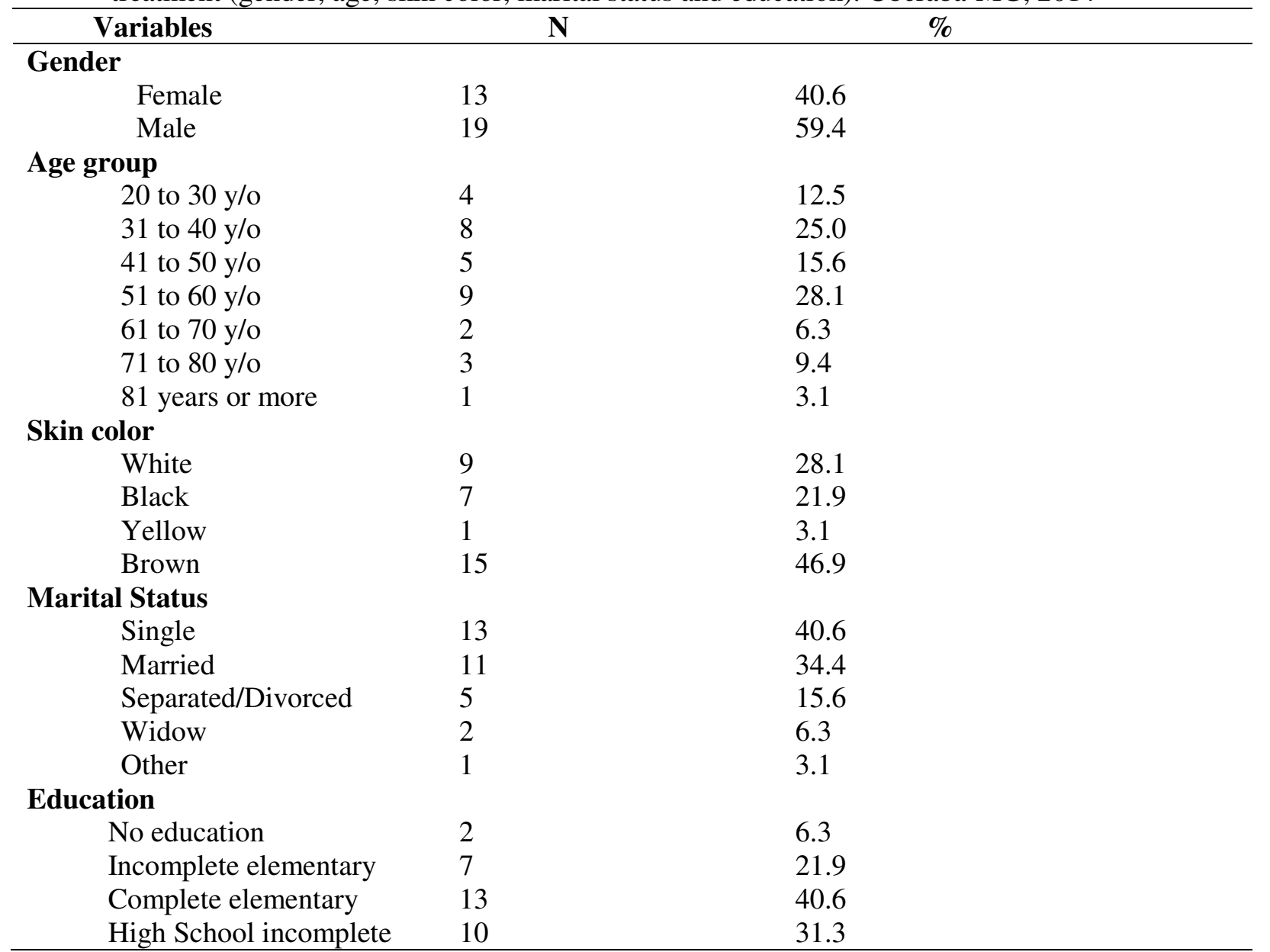

Note: The classification of the Brazilian Institute of Geography and Statistic (2011) was used in the original work, regarding the variable skin color.

Table 2. Socioeconomic/demographic characterization of patients diagnosed with Hansen's disease who are being treated (familial income, occupation, whether or not the participant was working when he found about his illness, current situation and housing). Uberaba-MG, 2014

\begin{tabular}{lll}
\hline \multicolumn{2}{c}{ Variables } & $\mathbf{N}$ \\
\hline Familial income & 5 & 15.6 \\
No permanent income & 9 & 28.1 \\
Up to 1 minium wage (MW) & 14 & 43.8 \\
$>1$ and up to 3 MW & 3 & 9.4 \\
$>3$ and up to 5 MW & 1 & 3.1 \\
> 5 MW & & \\
Occupation & 4 & 12.5 \\
Trader & 4 & 12.5 \\
Bricklayer & 2 & 6.3 \\
Seamstress & 4 & 12.5 \\
Student & 1 & 3.1 \\
Street cleaner & 4 & 12.5 \\
Salesperson & 2 & 6.3 \\
Manicure & 1 & 3.1 \\
School cook & &
\end{tabular}


Housewife/husband $\quad 5 \quad 15.6$

Retired $\quad 5 \quad 15.6$

Was working when found out about the disease

$\begin{array}{lll}\text { Yes } & 20 & 62.5\end{array}$

$\begin{array}{lll}\text { No } & 12 & 37.5\end{array}$

Current situation

$\begin{array}{lll}\text { Unemployed } & 12 & 37.5\end{array}$

Employed $\quad 6 \quad 18.8$

$\begin{array}{lll}\text { Self-employed } & 9 & 28.1\end{array}$

Housewife/husband $\quad 5 \quad 15.6$

\section{Housing}

Owns own house $\quad 11 \quad 34.4$

$\begin{array}{lll}\text { Rents } & 19 & 59.4\end{array}$

Lives in institution $\quad 1 \quad 3.1$

Other 113.1

Table 3 follows, containing data regarding the disease's characteristics and trajectory in

Hansen's disease patients who are already being treated.

Table 3. Data regarding Hansen's disease characteristics and trajectory in patients who were diagnosed and are being treated for it (first symptoms, first health service they went to, how long from the appearance of the first symptoms until the beginning of the treatment, how long until treatment started). UberabaMG, 2014

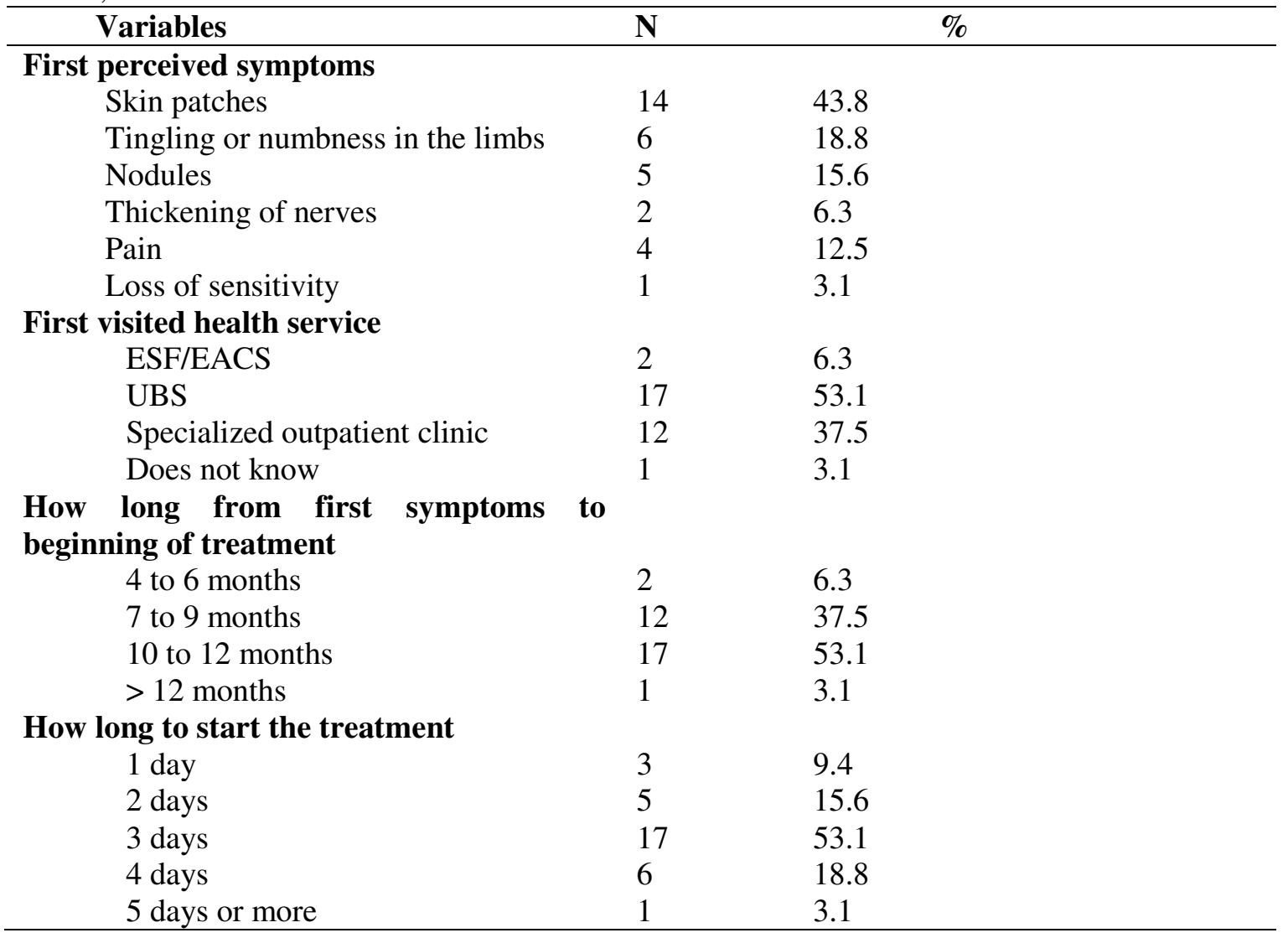

To these non-evaluated patients, undergo the treatment for the multibacillary strain. Thanks to the operational classification, the variable "treatment undergone" indicates that $84.4 \%$ of people are being treated for the multibacillary strain, and $15.6 \%$ for the paucibacillary (Table 3). These data are approximately $3.1 \%$ different from the results of the variable "operational classification". That is because there is one paucibacillary patient which, by medical recommendation, is undergoing a multibacillary 
treatment. It was noticed that $50 \%$ of respondents related to live with two to four people, and the number of people who are in touch with the diseased and have been examined, it was noticed that in $43.8 \%$ of cases only one person was examined. Data collected express a difference between the average number of people who live in the same house as the patient, and the number of people who are in touch and have been examined. The average of people living in the same house was 2.44 people, and the average of examined people in touch was of 1.75 people. That data was acquired through the examination of the medical records of the patients (Table 4).

Hansen's disease can also be classified according to one's degree of physical disability. The degree 0 is attributed when there is no neural compromising in the eyes, hands or feet; the degree 1 indicates a diminishing or loss of sensibility in the eyes, hands or feet; and the degree 2 indicates the existence of physical disabilities such as lagophtalmos and/or ectropion, trichiasis, opacity in the center of the cornea, and others (BRASIL, 2008).

Data was obtained through the medical record of patients being treated at the Health Center Professor Eurico Vilela, and as such can be considered as secondary data. We have observed that $37.5 \%$ of the interviewed were evaluated with physical disability of degree $1,18.8 \%$ had a degree 0 of disability, and the same number of patients had a degree 2. Among the analyzed medical records, $25 \%$ had not been evaluated regarding physical disabilities.

Table 4. Data regarding Hansen's disease characteristics and trajectory in patients who were diagnosed and are being treated for it (operational classification, clinical type, treatment undergone, number of people in the patients' house, number of known people examined and treatment abandonment). Uberaba-MG, 2014

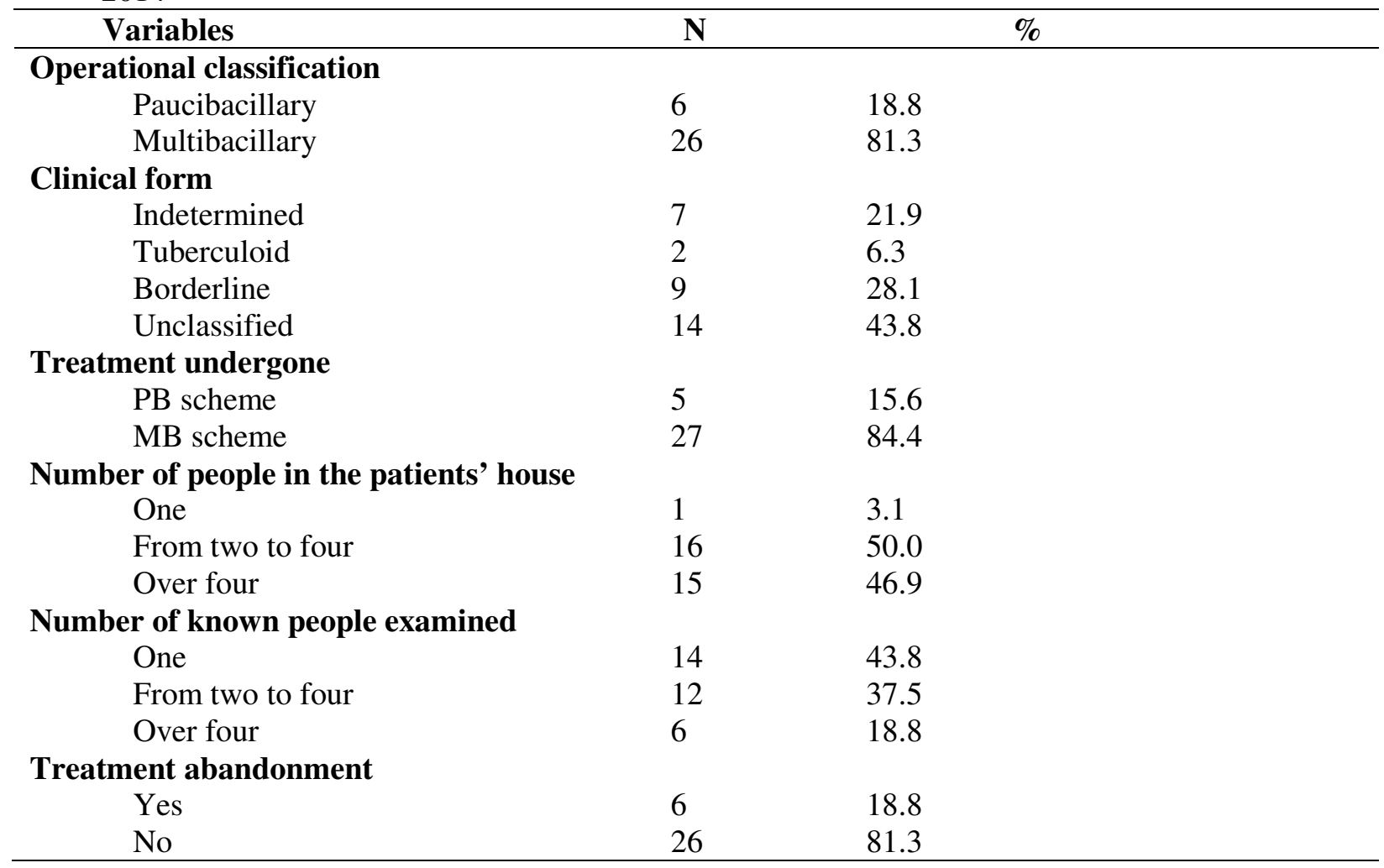

After looking for a correlation among the disability degree and age, familial income, education and current occupation, some statistically meaningful connections have surfaced (Table 5). There is a correlation between age and second degree disability, a weak and negative correlation which suggests that, as age grows, disability level increases. Degree 2 disability and familial income also have a weak and negative correlation, that is, the minor the familial income, the less the disability degree. Current occupation and second degree disability also had a weak and negative correlation, which shows that the greater the disability level, the less the possibility that the patient is economically active. Regarding the variable education, a weak and negative correlation with the second degree disability is indicative that the patients with higher disability have less years of education. 
Table 5. Correlations between the disability degree and age, familial income, education and current occupation of patients diagnosed with Hansen's disease who are under treatment. Uberaba-MG, 2014.

\begin{tabular}{|c|c|c|c|c|c|c|c|c|}
\hline \multirow[t]{2}{*}{$\begin{array}{c}\text { Disability } \\
\text { degree }\end{array}$} & \multicolumn{2}{|c|}{ Age } & \multicolumn{2}{|c|}{$\begin{array}{c}\text { Familiar } \\
\text { income }\end{array}$} & \multicolumn{2}{|c|}{ Education } & \multicolumn{2}{|c|}{$\begin{array}{c}\text { Current } \\
\text { occupation }\end{array}$} \\
\hline & $\mathbf{r}^{\mathbf{a}}$ & $\mathbf{p}^{*}$ & $\mathbf{r}^{\mathbf{b}}$ & $\mathbf{p}^{*}$ & $\mathbf{r}^{\mathbf{a}}$ & $\mathbf{p}^{*}$ & $\mathbf{r}^{\mathbf{a}}$ & $\mathbf{p}^{*}$ \\
\hline Degree 0 & -0.23 & 0.53 & -0.26 & 0.76 & -0.13 & 0.46 & -0.17 & 0.13 \\
\hline Degree 1 & -0.18 & 0.47 & -0.22 & 0.28 & -0.28 & 0.28 & -0.26 & 0.48 \\
\hline Degree 2 & -0.29 & $0.02 * *$ & -0.27 & $0.03 * *$ & -0.25 & $0.04 * *$ & -0.16 & $0.04 * *$ \\
\hline
\end{tabular}

${ }^{\mathrm{a}}$ Pearson correlation. ${ }^{\mathrm{b}}$ Spearman correlation; ** Significative results $(\mathrm{p} \leq 0.05)$

\section{DISCUSSION}

In Table one, regarding the gender of the patients, one can see that most are men $(59.4 \%)$. That also happens in other studies, where Hansen's disease is more common among males (RODINI et al., 2010; FINEZ; SALOTTI, 2011).

A research conducted by Melão and collaborators (2011) has found that 43 years old is the most affected age, and the most prevalent age group is the one between 20 and 49. In this research, it was noted that the most prevalent age group was from 51 to 60 years $(28.1 \%)$, followed by the age group from 31 to 40 years (25.0\%). In both studies, patients are in the middle of working age, and with the surfacing of the symptoms their productivity is compromised, and they often need to get licenses from their jobs (SOUSA et al., 2013). The discrete increase in the age group found in our study can be justified by the aging of the Brazilian population and by the fact that a significant number of people don't finish the treatmeant (ABRAÇADO; CUNHA; XAVIER, 2015). It can also be seen that as the individuals age grows, their immune system becomes weaker, starting to be more susceptible to infectious diseases (SOUSA et al., 2013).

The most common skin color was brown $(46.9 \%)$, as it was in the studies conducted by Melo and collaborators (2017) and Vieira, Carvalho and Sousa (2014). People of no particular skin color are predisposed to be infected by the bacillus that provokes Hansen's disease, and the prevalence of brown skinned people can be attributed to the miscegenation of the Brazilian population (MELO et al., 2017).

Data regarding marital status were not according to other studies, as in this research, $40.6 \%$ of people are single, while in the study conducted by Sousa and collaborators (2013) married people were more prevalent. The percentage of married people was also greater in the research conducted by
Baldan and Santos (2012), with 56\%. According to Baldan and Santos (2012), the marital state is paramount when it comes to the quality of life during the diagnosis and treatment of Hansen's disease. Therefore, a marital status which is not seen as sTable can negatively affect the patients quality of life.

The information about education shows that $40.6 \%$ of respondents have completed elementary school, while other researches have found that most their participants did not (SOUSA et al., 2013; SOUSA et al., 2017). Sousa and collaborators (2013) states that almost half of the population of his study has an incomplete elementary school, while Sousa and collaborators (2017) have found that $61,7 \%$ of their participants were in the same situation. The research conducted by Melo and collaborators (2017) has found a result similar to ours when it comes to education, $22,58 \%$ of its participants had completed elementary school. In a general sense, low education is a significant risk factor for Hansen's disease, and also for the abandonment or nonacceptance of treatment (MELO et al., 2017; ABRAÇADO et al., 2015).

According to some authors, a low income is one of the most relevant factor. These researches add that tuberculosis, schistosomiasis, Chagas disease, dengue, leishmaniosis and malaria, together with Hansen's disease, are diseases considered to be neglected, and are endemic to low income population (ABRAÇADO et al., 2015). In Table 1, it can be noted that most people, $43.8 \%$, are patients with familial income between one and three minimum wages. However, it is important to mention that $28.1 \%$ earns up to one minimum wage. A similar result was found in a research where $90 \%$ of participants had an income of up to three minimum wages (BALDAN; SANTOS, 2012), and in other study where $28,6 \%$ received less than one minimum wage (ABRAÇADO et al., 2015) . The influence of the economic aspect, when put together 
with social and psychological aspects, strongly impacts the confronting of the disease and the maintenance of health, leading to a diminishing of the quality of life (SOUSA et al., 2013).

Regarding the occupation, our results were similar to those of Sousa and collaborators (2013). The occupation and low education found impose limits, both to the possibility of achieving a better position, with a better salary, and to the accomplishing of orientations given by health professionals regarding the disease, its treatment, and the prevention of physical disabilities (ABRAÇADO et al., 2015). It is also possible to notice that $37.5 \%$ are unemployed, $28.1 \%$ have reported to be self-employed, and $15.6 \%$ are houseworking. Only $18.8 \%$ are unemployed. Regarding the variable "had a job when found about the disease", $62.5 \%$ reported that they did (Table 1).

Regarding the search for health services when the first symptoms appeared, the importance of Primary Health Care (UBS) units is highlighted, that is, the UBS units that have a Strategy for the Health of Families (EFS), which guarantee that the population has a better access (BALDAN; SANTOS, 2012). Since April, 2014, patients diagnosed with Hansen's disease who came from places other than the city of Uberaba, MG, have been directed by the specialized outpatient clinic Health Center Professor Eurico Vilela to the health centers of their own cities. That is, they are examined in this specialized center, but their treatment is continued in their city of origin. That happens as a decentralizing tactic and logistical support to the patients, and aims at offering a better prognostic with an easier conduction, as well as better follow up to the cases and a diminishing of abandonments. It is relevant to ask how much a break in the transmission chain is treated as a priority by the Pact for Life recommended by the Ministry of Health, which is a policy to include actions and measures so that the time spent between the appearance of the first symptoms, the search for a health service and the beginning of the treatment become increasingly lower (BRAZIL, 2006), breaking the chain and by consequence diminishing the number of new cases.

The results regarding operational classification corroborate studies which analyzed, through SINAN, 93 patients between 2010 and 2014 and found 44 of paucibacillary ones and 49 multibacillary ones (MELO et al., 2017). Data found by Kill and collaborators (2012) have also been similar, with $62,9 \%$ of multibacillary participants. There was, however, a meaningful difference between the studies regarding the unevaluated cases.
According to Vieira and collaborators (2014), it would be paramount for other forms of diagnoses to be used in order for a differential diagnose to be obtained, thus leading to a diminishing in the notifications of unevaluated forms.

Another factor which influences heavily in the decreasing of cases and the achievement of early diagnosis is the control and evaluation of the people who are close to the patient, even during treatment, specially those who live in the same house (RAPOSO; NEMES, 2012).

According to Sousa and collaborators (2013), some studies still reflect the stigma related to the diagnosis of Hansen's disease, the suffering that the segregation brought upon the patients in the past, and still brings nowadays. Thus, the fear of the reality of the diagnose leads to a probable omission, which is felt as a self-preservation act, aimed at avoiding prejudice and rejection (ROCHA et al., 2011). Such omission was also reported by Sousa and collaborators (2013) in his research, whose objective was to investigate the changes in the life of the patients diagnosed with Hansen's disease and the adhesion to treatment. It was reported that, sometimes, a "lie" or the hiding of the truth becomes necessary in order for a patient to keep their job or even their social relationships.

A study conducted in Rio de Janeiro by Reis, Gomes e Cunha (2013), with patients who underwent a neurolysis surgery, found data similar to ours when it comes to the degrees 0 and 1 of physical disability: $50.0 \%$ of degree $1,33.3 \%$ of degree 2 , and $16.7 \%$ for degree 0 . This result also corroborates the research conducted by Rodini and collaborators (2010), where the first degree of disability was also prevalent. But in one study, the physical disabilities of the second degree were more common (FINEZ; SALOTTI, 2011).

The greatest percentage of first and second degree physical disability indicates late diagnoses, and is provoked by the evolution of the disease and the absence of treatment and follow up (BRASIL, 2008). A research has indicated that this situation can be explained by public health policies which do not have visibility, and reveals a greater incidence of multibacillary Hansen's disease cases than that of paucibacillary cases. That makes it so the physical harm provoked by the disease is more serious, as it is the most dangerous form of the disease. Thus, the physical disability levels become greater (FINEZ; SALOTTI, 2011).

A study conducted in Uberaba, MG, in the period from 2000 to 2006 has found that $66.2 \%$ of patients were evaluated regarding their physical disability levels (MIRANZI; PEREIRA; NUNES, 
2010), percentage which is lower than the one found in this research, where $75.0 \%$ of participants were evaluated. Even though there has been an increase in the frequency of evaluations, it is important to mention that this procedure should be conducted in its entirety, as it is a measure of Hansen's disease morbidity, and relates to the findings of some degree of physical disability in the moment a late diagnosis is performed.

The results of this research have made it possible to understand better the population studied and their reality. Even though the final sample was small, its representativeness due to the importance of the city of Uberaba for the treatment and prevention of the disease made it possible to conclude that a humanized evaluation of patients should be routinely conducted, as the active search for new cases would help in the achievement of early diagnoses. That could be made a priority to multidisciplinary health teams, in order to avoid the physical disabilities and sequelae which significantly compromise the quality of life of this population.

RESUMO: Esse estudo possuiu como objetivo destacar as condições socioeconômicas e demográficas, as características clínicas, a trajetória da doença e o grau de incapacidade física de pessoas com hanseníase. Métodos: Foi um estudo observacional, transversal e quantitativo. Desenvolvido na cidade de Uberaba/MG durante setembro e agosto de 2014. A população do estudo foi composta por todos os pacientes diagnóstico com Hanseníase, que estavam em tratamento por pelo menos 30 dias $(n=32)$. Resultados: A maioria dos indivíduos era do sexo masculino (59,4\%). Média de 49,28 anos. 46,9\% eram pardos, 40,6\% eram solteiros e 40,6\% tinham ensino fundamental completo. Manchas na pele foi o sintoma mais percebido (43,8\%). $81,3 \%$ dos pacientes apresentava a forma multibacilar e 18,8\% a paucibacilar. $\mathrm{O}$ grau de incapacidade física foi de $18.8 \%$ para grau $0,37,5 \%$ para grau 1 e 18,8\% para grau 2 . Correlações foram encontradas entre idade, renda familiar e o estado atual de ocupação e escolaridade, com o grau 2 de incapacidade física. Conclusões: A avaliação dos pacientes deveria ser conduzido de forma rotineira, pois poderia auxiliar no diagnóstico precoce, que por sua vez poderia minimizar as sequelas e incapacidades físicas que influenciam significativamente a qualidade de vida dessa população.

PALAVRAS-CHAVE: Hanseníase. Perfil de saúde. Estudos populacionais em Saúde Pública.

\section{REFERENCES}

ABRAÇADO, M. F. S.; CUNHA, M. H. C. M.; XAVIER, M. B. Adesão ao tratamento de hanseníase em pacientes com episódios reacionais hansênicos em uma unidade de referência. Revista Pan-Amazônica de Saúde, v. 6, n. 2, p. 23-28, 2015. Available in: http://scielo.iec.pa.gov.br/pdf/rpas/v6n2/v6n2a03.pdf Access in: 01 ag. 2017.

BRASIL. Ministério da Saúde. Guia Para o Controle da Hanseníase - Cadernos da Atenção Básica No 10 Série A: Normas e Manuais Técnicos; Nº111. ATDS/SPS/Ministério da Saúde - Brasil. 1. ed. Brasília: Ministério da Saúde, 2002. 89 p.

BRASIL. Ministério da Saúde. Diretrizes operacionais dos Pactos pela Vida, em Defesa do SUS e de Gestão. 2. ed. Brasília: Ministério da Saúde, 2006.

BRASIL. Ministério da Saúde. Secretaria de Vigilância em Saúde. Manual de prevenção de incapacidades. 3. ed. Brasília (DF): Ministério da Saúde, 2008

BRASIL. Ministério da Saúde. Secretaria de Vigilância em Saúde. Departamento de Vigilância das Doenças Transmissíveis. Guia prático sobre a hanseníase. 1. ed. Brasília: Ministério da Saúde, 2017. 68 p.

BRASIL. Ministério da Saúde. Secretaria de Vigilância em Saúde. Boletim Epidemiológico. v. 39, n. 4. Brasília: Ministério da Saúde, 2018. 
FINEZ, M. A.; SALOTTI, S. R. A. Identificação do grau de incapacidades em pacientes portadores de hanseníase através da avaliação neurológica simplificada. Journal of the Health Sciences Institute, v. 29, n. 3, p. 171-175, 2011. Available in: http://www.unip.br/comunicacao/publicacoes/ics/edicoes/2011/03_julset/V29_n3_2011_p171-175.pdf Access in: 15 jul. 2017.

KIL, A. K. A. et al. Deficiências e incapacidades por hanseníase: avaliação clínica e epidemiológica dos pacientes atendidos em um Centro de Referência Nacional do Brasil. Hansenologia Internationalis, v. 37, n. 1, p. 25-33, 2012. Available in: http://periodicos.ses.sp.bvs.br/scielo.php?script=sci_arttext\&pid=S198251612012000100003\&lng=pt\&nrm=iss Access in: 15 jul. 2017

LOBATO, D. C.; NEVES, D. C. O.; XAVIER, M. B. Avaliação das ações da vigilância de contatos domiciliares de pacientes com hanseníase no Município de Igarapé-Açu, Estado do Pará, Brasil. Revista PanAmazônica de Saúde, v. 7, n. 1, p. 45-53, 2016. Available in: http://scielo.iec.pa.gov.br/pdf/rpas/v7n1/v7n1a06.pdf Access in: 30 jul. 2017

MELÃO, S. et al. Perfil epidemiológico dos pacientes com hanseníase no extremo sul de Santa Catarina, no período de 2001 a 2007. Revista da Sociedade Brasileira de Medicina Tropical, v. 44, n. 1, p. 79-84, 2011. Available in:

https://www.researchgate.net/profile/Priscyla_Waleska_Simoes/publication/278716715_Perfil_epidemiologico _dos_pacientes_com_hanseniase_no_extremo_sul_de_Santa_Catarina_no_periodo_de_2001_a_2007/links/572 b3e0108ae2efbfdbdd105.pdf Access in: 30 jun. 2017

MELO, J. P. et al. Perfil epidemiológico dos casos de hanseníase de uma unidade de Saúde. Revista de Saúde Coletiva da UEFS, v. 7, n. 1, p. 29-34, 2017. Available in: http://periodicos.uefs.br/ojs/index.php/saudecoletiva/article/view/1176/1279 Access in: 15 jul 2017.

MIRANZI, S. S. C.; PEREIRA, L. H. M.; NUNES, A. A. Perfil epidemiológico da hanseníase em um município brasileiro, no período de 2000 a 2006. Revista da sociedade brasileira de medicina tropical, v. 43, n. 1, p. 62-67. 2010. Available in: http://www.epi.uff.br/wp-content/uploads/2016/09/hans.pdf Access in: 15 jul 2017.

MONTEIRO, L. D. et al. Incapacidades físicas em pessoas acometidas pela hanseníase no período pós-alta da poliquimioterapia em um municipio no Norte do Brasil. Caderno de saúde pública, v. 29, n. 5, p. 909-920, 2013. Available in: http://www.scielo.br/pdf/csp/v29n5/09.pdf Accesses in: 30 jun 2017.

ORGANIZACIÓN MUNDIAL DE LA SALUD. Prevención de Incapacidad y Rehabilitación. (Série de informes técnicos, 668). 1981.

RAPOSO, M. T.; NEMES, M. I. B. Assessment of integration of the leprosy program into primary health care in Aracaju, state of Sergipe, Brazil. Revista da Sociedade Brasileira de Medicina Tropical, v. 45, n. 2, p. 203-208, 2012. Available in <http://www.scielo.br/scielo.php?script=sci_arttext\&pid=S0037$86822012000200013 \& \operatorname{lng}=\mathrm{en} \& \mathrm{nrm}=\mathrm{iso}>$. Access in 18 jul. 2017.

REIS, F. J. J.; GOMES, M. K.; CUNHA, A. J. L. A. Avaliação da limitação das atividades diárias e qualidade de vida de pacientes com hanseníase submetidos à cirurgia de neurólise para tratamento das neurites.

Fisioterapia e Pesquisa, v. 20, n. 2, p. 184-190, 2013. Available in $<$ http://www.scielo.br/scielo.php?script=sci_arttext\&pid=S1809-29502013000200014\&lng=en\&nrm=iso $>$. Access in: 18 jul. 2017. http://dx.doi.org/10.1590/S1809-2950201300000014.

ROCHA, A. C. P. et al. O discurso coletivo de ex-hanseniano morador de um antigo leprosário no NordesteBrasil. Interface: Comunicação, Saúde, Educação, v. 15, n. 36, p. 213-223, 2011.

https://doi.org/10.1590/S1414-32832011000100017 
RODINI, F. C. B. et al. Prevenção de incapacidade na hanseníase com apoio em um manual de autocuidado para pacientes. Fisioterapia e Pesquisa, São Paulo, v. 17, n. 2, p. 157-166, abr/jun. 2010. Available in: https://www.revistas.usp.br/fpusp/article/view/12189/13966 Access in: 30 jun 2017.

SOUSA, A. A. et al. Adesão ao tratamento da hanseníase por pacientes acompanhados em unidades básicas de saúde de Imperatriz-MA. SANARE, v. 12, n. 1, p. 06-12, 2013. Available in:

http://repositorio.ufc.br/ri/bitstream/riufc/7588/1/2013_art_acpjcosta1.pdf Access in: 30 jun. 2017

SOUSA, G. C. et al. Caracterização clínico-epidemiológica de casos de hanseníase com incapacidades físicas. Revista da Rede de Enfermagem do Nordeste, v. 18, n. 1, p. 99-105, 2017. Available in:

http://periodicos.ufc.br/rene/article/view/19219/29936 Access in: 15 jul. 2017

VIEIRA, G. D. et al. Hanseníase em Rondônia: incidência e características dos casos notificados, 2001 a 2012. Epidemiologia e Serviços de Saúde, v. 23, n. 2, p. 269-275, 2014. Available in: http://scielo.iec.pa.gov.br/pdf/ess/v23n2/v23n2a08.pdf Access in: 15 jul. 2017

WORLD HEALTH ORGANIZATION/WHO. The world health report 2001. Mental health: new understanding new hope. Genebra: WHO; 2001. 